Fellows, and learn the latest on the Fellowship Program. An address will be given by the Outstanding Legislator of the 100th Congress, as selected by Congressional Fellows. In addition, Frederick L. Holborn will be honored for his many years of service to the Congressional Fellowship Program.

The reception and dinner will be held on Thursday evening, September I from 6:00 to $9: 00 \mathrm{pm}$ at the Dupont Plaza Hotel, 1500 New Hampshire Avenue, NW. The cost is $\$ 30.00$ per person, and current and former Fellows may invite a spouse or friend. Send your check, payable to "APSA-CFP" to Len Parkinson, 6724 Weaver Avenue, McLean, Virginia 22101.

Fellows who cannot attend should let APSA know of their current address and occupation for the next edition of the Congressional Fellowship Directory.

If you have any questions about the dinner, please contact Len Parkinson, President of the Alumni Association, at (703) 642-4169.

\section{William D. Zaferos Named Poynter Fellow}

William D. Zaferos, state and national political reporter for the Appleton, Wisconsin, Post-Crescent, has been named the 1987-88 Poynter Fellow in the Congressional Fellowship Program.

As a Congressional Fellow, Zaferos is serving as legislative aide to Norman Mineta (D-CA).

For the past five years The Poynter Fund has generously provided direct support for APSA journalism Fellows, and this is the third year the Fund has supported a named Poynter Fellow. The first was Celia Cohen, senior statehouse reporter for the Wilmington News-Journal newspapers. Last year's Poynter Fellow was Andrew Pollack, reporter for The Democrat and Chronicle in Rochester, New York.

The Poynter Fund is the charitable foundation of the Times Publishing Company whose publications include Congressional Quarterly Weekly Report and the family of publications of Congressional Quarterly,

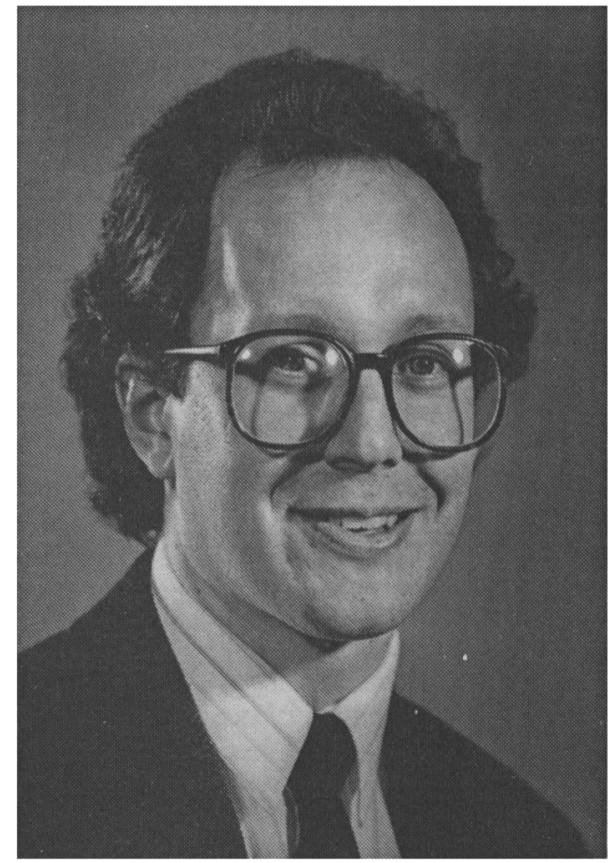

WILLIAM D. ZAFEROS

Inc., as well as the St. Petersburg Times and Evening Independent. Eugene Patterson serves as President of The Poynter Fund and Chairman of the Board and Chief Executive Officer of Times Publishing Company.

\section{Jay Kohn Awarded Joan Shorenstein Barone Congressional Fellowship}

Jay A. Kohn, capitol bureau chief for the Montana Television Network, is the 1987 . 88 recipient of the Joan Shorenstein Barone Congressional Fellowship. He is the second individual to win the Fellowship, awarded each year to a broadcast journalist of outstanding merit.

Kohn is currently working on the personal staff of Representative Dick Cheney (R-WY), Chairman of the House Republican Conference. 